\title{
The Use of Technology in English Language Teaching: A Literature Review
}

\author{
Mustafa Altun ${ }^{1} \&$ Hassan Khurshid Ahmad ${ }^{2}$ \\ ${ }^{1,2}$ English Language Teaching Department, Faculty of Education, Tishk International University, Erbil, \\ Iraq \\ Correspondence: Mustafa Altun, Tishk International University, Erbil, Iraq \\ Email: mustafa.altun@tiu.edu.iq
}

Doi: 10.23918/ijsses.v8i1p226

\begin{abstract}
Technology is one of the important factors of progressing the teaching/learning process in the schools and universities especially for the English language teaching. It can help the teacher to present a better lesson to students. Technology is very necessary for the field of education because there are too many things that the teachers can do such as playing videos in English language or a song, movie and even a theatre show. Now a days using technology is very common in the world; however, Kurdistan public schools do not use any technology in their classes except the private schools. The ministry of education has neglected this most important factor in this age. In the pandemic most of the countries faced problems in studying in the schools because of the lock down. Most countries seek to use the technology to finish the school year and they successfully finished their school year by using E Learning and Online Zoom even other resources to rich the learning process but in Kurdistan the schools do not use any kinds of technology and our students are not familiar with the online systems and $E$ learning because we do not apply such valuable recourses in our schools that's why in this year we have encountered a lot of problems of finishing the schools year because our students did not know how to use and access them easily. In this research my aim is to find out the advantages and disadvantages of using technology in the education and what are the reasons for not using technology in Kurdistan schools until now.
\end{abstract}

Keywords: Technology, Education, English Language, Ministry of Education, E Learning

\section{Introduction}

Technology works best when it is used as a tool to help solve problems. For instance, in-person immersion is a desirable way to speed up language training, since all activities must be completed using the English language. But it is simply not possible for most people to pick up and travel to a country that speaks the language you want. With technology, students can still benefit from immersion. Thanks to messaging and social networks from the next generation, remote students can access fluent speakers of the languages they study and deliver real language practice in conventional classrooms.

Received: January 4, 2021

Accepted: March 10, 2021

Altun, M., \& Ahmad, H.K. (2021). The Use of Technology in English Language Teaching: A Literature Review. International Journal of Social Sciences \& Educational Studies, 8(1), 226-232. 
Dynamic resources encourage a sense of unity and engaging learning experiences, enable students to take part in classes if they are convenient and eliminate barriers to space and time. Generally, technologyenabled learning environments promote more consistent student interaction and give students access to peers and teachers around the globe and worldwide. The analysis revealed that such technology increases student engagement and focus, as it enables students to communicate with one another in the realistic processes of language learning. The usage and positive effect in classrooms of multimedia technology on the learning process is associated with the evolving productivity of the teacher role (Shyamlee, 2012, p. 155).

Technology provides even hundreds of resources in real time to assist students. Students can use simplified dictionaries, make flashcards, and explore the internet in the language they are learning. You can find colleagues, conversational partners and tutors online. They will find rich examples of the languages they study, not just static examples from traditional textbooks. Technology may also increase the quality of language learning in traditional environments. For instance, the learners may record themselves in the foreign language they learn and bring their feedback and reviews into the classroom. Learners can use technology during class to interact with each other via text chat instead of speaking, since it gives the learner time to focus and evaluate their performance.

Teachers can see how their students perform, by offering useful information about what kind of practice is required by learners. Teachers should adapt their teaching practices and educational approach to the needs of learners and make the whole process much more efficient and effective. For instance, a teacher who understands that all her/his students struggle to read passages that contain examples of the future tense should review them in the classroom, not waste time with examples that do not meet the group's needs. Technology can be a precious part of an overall language learning approach when it is used to address challenges creatively and/or improve language learning processes.

\section{Literature Review}

\subsection{The Importance of Technology}

Technology is a process, method, or knowledge used to carry out a task. On this definition, we define technology as a learning task or instructional objective using technical processes, methods, or knowledge within the context of this study. For instance, the learner can complete a speech task by describing an object's characteristics in the target language and by using a digital voice recorder to record their speech to play it to their teacher later on (Merriam-Webster Dictionary, 2019). Using classroom technology encourages English students to promote their success in English. In addition to the traditional methodologies, technology offers many learning opportunities. Teachers therefore have many resources and materials for their lessons. Cutter also explains the increase in engagement in technology. Students are motivated more while they are working on computers and use modern devices than they are working with textbooks (Cutter, 2015).

They are often less distracted and for each student the teacher can choose personal lessons according to their needs. In addition, students can use their home appliances to complement their knowledge. In the learning environment, technology has always been a major factor. It is an important part of the teacher 
profession that can be used to make learning easier for learners. The word "integration" is used when we speak of technology in teaching and learning. As technology is part of our daily lives, it is time to reconsider the idea of integrating technology into your curriculum and to integrate technology into teaching in order to support the learning process. From this we can see that technology flourishes the teachers' abilities and helps them to have a wide range of opportunities in teaching students' the English language, for instance displaying videos or songs in English language related to the subject that the teacher explains will help the students to understand faster and have a better view toward the subject.

The use of new-generation technology gives students a natural context for learner autonomy, context for the identity of learner, new ways of language use, and motivation for students to create new collaborative and interaction opportunities between teachers and students under these forms (Murray, 2005). Technology plays an important role in promoting learners' activities and has a substantial impact on teaching methods. If teachers do not use technology in teaching, they cannot keep up with this technology. Therefore, teachers must have complete expertise in teaching language skills in these technologies (Pourhosein Gilakjani, 2017; Solanki \& Shyamlee, 2012). Potential technological approaches that could play an important role in teaching, especially in speaking and listening, are also provided by Nomass. He stated that English language learners can learn, including the use of web-based language learning programs, innovative presentations software, dictionaries, chat functions and emails, and computerassisted language learning programs. The research was carried out in the case study tradition and focused on the use of technology in the school to learn the English language by a group of students. Nomass highlights the current technology issues in classrooms in his recommendations for future research and how these can be taken into account. The problems include the division in the modern classroom between theory and practice. He called for technology integration into the language learning practice at these schools and stated that educators should take these kinds of innovations into account too (Nomass, 2013).

\subsection{Integrating Technology in the Classroom}

Internet usage increases the motivation of students. The use of film in education helps students to understand and develop their knowledge with enthusiasm. Students can use technology in their learning processes via computer and the internet to learn effectively. It helps students develop their higher level of thinking skills when they are learning with technology. In conclusion, it is very important to draw the attention of learners to English languages, the true combination of the multimedia and teaching methodology (Arifah, 2014). Two different perspectives on how technology can be integrated in a classroom were described. First, with the cognitive approach, students have the opportunity to maximize their language exposure and build their own individual knowledge in a meaningful setting. The textreconstruction software and multimedia simulation software are examples of these types of technologies. Multimedia simulation software enables learners to enter computerized micro-worlds in a meaningful audio-visual context, with a focus on language and culture. The best of these programs allows students to control and interact much so that their linguistic input can better be manipulated Secondly, the social approach underlines the social dimension of language learning, where linguistic learning is seen as a socialization process. In that context students need to be able to practice real-life skills by genuine social interactions. This can be done through authentic tasks and projects in collaboration with students (Warschauer, 2000). 
A key element of language learning is pronunciation. However, it is difficult to provide helpful feedback. A teacher who may or may not be good at first assessing the student's statement frequently provides comments and modeling in traditional instructional contexts. Typical feedback means that students should repeat the pronunciation or explain how the sound should be produced abstractly. The student can receive feedback in more efficient and efficient ways by advancing speech recognition technology (Zhoa, 2013). The use of technology in classrooms in English as a foreign language can provide an important and attractive approach to linguistic study. It motivates the students and makes them easier to talk, read, listen and write (Ilter, 2009). However, technology is not enough to teach ELLs alone. It needs a teacher with clear targets, who knows the curriculum and effective education strategies and can provide children with learning experiences to increase and encounter with previous knowledge (Schwartz \& Pollishuke, 2013). A study has demonstrated that Wiki technology improves the written skills of students. The students were invited to join a Wiki page to write passages and then read and answer their classmates' passages. Learners said that using this kind of technology would benefit the immediate feedback they received. Another discovery was that students learned vocabulary, spelling, and sentences by reading their classmates' work (Lin and Yang, 2011).

A study showed that using technology to improve the reading and writing skills of learners. The results of this study showed that the tools used in technology enhance the ability of learners to write and read because they are user friendly. The other results of this study were that leaners learn more efficiently by using technology tools instead of traditional teaching methods because the Internet provided a conducive learning environment for learners and provided a new platform for students who can access learning lessons in a convenient way (Peregoy \& Boyle, 2012). Technology assists students and teachers in their quick access to course materials. Technological advances have an essential role to play in preparing students for what they learn to find their way into the global workforce in any subject. Technology facilitates learning for learners and serves as a real learning tool (Rodinadze \& Zarbazoia, 2012). This research study was carried out to provide schools with information about iPads and applications in the classroom, identify critical use of teaching and learning table technologies, and identify appropriate teacher learning opportunities. In this study, $75 \mathrm{iPads}$ were acquired and distributed to three primary schools including five teachers and more than 90 students during the second semester of 2011. This research provided important insights into the use of iPads and apps and their impact on teaching and learning in primary classrooms. Although the iPad demanded additional time from teachers, as it took a long time to evaluate educational apps and their curriculum relevance and install them on individual student appliances, researchers noted some alignment of the curriculum and apps in the iTunes App Store. $43 \%$ of the apps were actually classified as informative. Teachers believed that they had the best use of the iPads by using content creation applications because this gave students a higher level of understanding and creativity, The Sydney Region, in Australia (NSW Curriculum and Learning Innovation Centre, 2012). Another advantage noticed by teachers was increased student collaboration (Goodwin, 2012).

The use of computers and other technological devices should be encouraged, since this can increase the motivation of students in English courses and can achieve efficient and successful goals. However, he stresses that the teacher must not believe that technology can be used as the sole motivation, and that all lessons are based on careful use of technology and strong educational considerations (Ilter, 2009). The use of technology in the teaching concepts has found that there has been a significant increase in the motivation 
of students. Before students had internet access at school, they were confined to social studies in classroom books and those which could be found in school library. Open Internet access offers students the tools for research today and for deeper learning (Gustad, 2014).

\subsection{The Impact of Technology on Language Learning at an Early Age}

Technology offers teaching resources and provides children with learning experience in the world. Technology also offers many authentic materials and young learners in a long language learning atmosphere can easily become motivated. Mart (2017) argues that authentic materials are good models for learners to process real language in context. Larsen-Freeman and Anderson (2011) mention that for language learners electronic chat, games, and pan-pals and podcasts may be interesting. In general, children are visual students. They want to see as they learn. Internet and computer-based activities provide children's worlds with visual materials. Children can improve their listening, reading, and writing abilities in the media and the Internet

The real value of English is experienced by young students through emails, the web, satellite TV and cable. Young students are energized, and it can be difficult sometimes to teach them foreign languages during their classes. Technology can provide young language learners with a genuine and enjoyable atmosphere and increase the awareness of their language when it is used correctly. Increasing awareness and understanding of language encourages learners to arrive at accurate meaningful interpretations of text (Mart, 2018). The technology also enables young learners who interact actively to acquire language skills outside the classroom (Larimer \& Schleicher, 1999; Brewster, Ellis, \& Girard, 2004). The fact that kids can lose their concentration in a short time. Often this period can be longer with the use of fun and authentic materials.

The internet offers many authentic materials to children. The socio-cognitive approach offers the opportunity for language learners to interact in a real social context. The internet can supply sociocognitive approach via tasks and project study. Online games can support and enhance various vocabulary fields and give positive insights in language feedback (Gee, 1996). Among the features that characterize the technology are the speed, high accuracy, and repetition of the lesson presented to it dozens of times in the same day, and also its great contribution to saving time and effort for the teacher. So, the repetition process helps the child a lot in memorization and comprehension the lesson significantly. Computer based activities offer quick information and excellent materials to language learners. Tomlinson (2009) also explains that multimedia and a variety of websites encourage student to understand more.

\subsection{Technology Makes Learning English Language Easier}

The use of technology has changed the teaching methods of English considerably (Altun, 2015). It offers so many options for the advancement of education to be interesting and productive (Patel, 2013). The use of multimedia text in class helps learners to learn the language structure and vocabulary. The use of multimedia also enhances learners' linguistic knowledge by using printed texts, film, and the Internet. The use of print, film and the Internet allows students to gather information and offers various materials for language analysis and interpretation as well as contexts (Arifah, 2014). The use of the internet enhances the motivation of learners. Using film in teaching helps students to understand and develop their 
knowledge with enthusiasm. Learners can learn meaningfully when technology is used through computer and internet in the process of learning. It helps students develop their higher-quality thinking skills when they learn technology. In conclusion, it is very important for students to focus on English learning through the real combination of the multimedia and teaching methodologies (Arifah, 2014).

The use of computer technology makes language class an active place full of meaningful tasks for students (Dawson, Cavanaugh, \& Ritzhaupt, 2008; Gilakjani, 2014). The results of this study show that the use of technology tools enhances the ability of learners to read and write because they are user-friendly. The other finding in this study was that lessons learned more effectively by using technological tools instead of traditional teaching methods as the Internet provided a favorable learning environment for learners (Peregoy, Boyle, 2012).

\section{Conclusion and Recommendations}

This study indicates that using technology in learning English language is very essential, having such technological tools in the classroom allows the teacher to use different methods and approaches in teaching his/her students. In addition, the studies that we talked about proof that technology is one of the important backbones in the modern era. It is very helpful in facilitating topics and assisting the teacher with the lessons. However, in Kurdistan's public schools we are suffering from lack of technological devices which is really a big disaster for our education sector. Moreover, there are schools in Kurdistan which have provided these necessities, but they are private schools. So, it is the government responsibility to provide such technological devices to public schools as well in order to maintain the equality between the society and to protect the rights of the lower-class people. At the end of this study, it appears that technology these days are very important in our lives and especially for teaching/learning. We have to take into consideration that students can take advantage from technological devices in gathering information, learning vocabularies, and listening to English discussions. Overall technology must be used in the classrooms for its importance and effectiveness.

\section{References}

Altun, M. (2015). The integration of technology into foreign language teaching. International Journal on New Trends in Education and Their Implications, 6(1), 22-27.

Arifah, A. (2014). Study on the use of technology in ELT classroom: Teachers' perspective. M.A. Thesis, Department of English and Humanities, BRAC University, Dhaka, Bangladesh.

Brewster, J. Ellis, G. Girard, D. (2004). The primary English teacher's guide. England: Penguin English Guides.

Cutter, M. (2015). Using technology with English language learners in the classroom. Education Masters. Paper 313.

Dawson, K., Cavanaugh, C., \& Ritzhaupt, A. (2008). Florida's EETT leveraging laptops initiative and its impact on teaching practices. Journal of Research on Technology in Education, 41(2), 143 159.

Eady, M. J., \& Lockyer, L. (2013). Tools for learning: Technology and teaching strategies: Learning to teach in the primary school. Queensland University of Technology, Australia. pp. 71-89.

Gee, J. P. (1996). Social linguistics and literacies. London: Taylor \& Francis.

Goodwin, K. (2012). Use of tablet technology in the classroom. South Wales, Sydney: NSW Curriculum and Learning Innovation Centre. 
Gustad, A. R. (2014). The impact of technology tools on literacy motivation on elementary school English language learners: Podcasting in a 4th grade EAL class. International Schools Journal, 34(1), 75-84.

Ilter, B.G. (2009). Effect of technology on motivation in EFL classrooms. TOJDE. 10(4), 1.

Larimer, R. E., \& Schleicher, L. (1999). New ways in using authentic materials in the classroom. New ways in TESOL Series II: Innovative classroom techniques. Waldorf: TESOL Publications.

Larsen- Freeman, D., \& Anderson, M. (2011). Techniques and principles in language teaching. Oxford: OUP

Lin, W., \& Yang, S. (2011). Exploring students' perceptions of integrating Wiki technology and peer feedback into English writing courses. English Teaching: Practice and Critique, 10(2), 88103.

Mart, Ç. T. (2017). Literary Texts: A Means to Promote Language Proficiency of Upper-Intermediate Level EFL Students. Journal of Education in Black Sea Region, 2(2), 44-55.

Mart, Ç. T. (2018). Literature in the language classroom: A recipe to maximize learning. L1Educational Studies in Language and Literature, 18, p. 1-25. https://doi.org/ 10.17239/L1ESLL2018.18.01.09

Merriam-Webster Dictionary; Merriam-Webster, Inc.: New York, NY, USA, 2016.

Murray, D. 2005 Technologies for second language literacy. Annual Review of Applied Linguistics, 25, $188-201$

Nomass, B. (2013). The impact of using technology in teaching English as a second language. English Language and Literature Studies, 3(1), 111-116.

NSW curriculum and learning innovation centre. (2012). Use of tablet technology in the classroom. Retrieved on March 5, 2014.

Patel, C. (2013). Use of multimedia technology in teaching and learning communication skill: An analysis. International Journal of Advancements in Research \& Technology, 2(7), 116-123.

Peregoy, S., \& Boyle, O. (2012). Reading, writing, and learning in ESL: A resource book for teachers. New York: Allyn \& Bacon.

Pourhossein, G.A. (2014). A detailed analysis over some important issues towards using computer technology into the EFL classrooms. Universal Journal of Educational Research, 2(2), 146-1.

Pourhossein A., \& Sabouri, N. B. (2017). Advantages of using computer in teaching English pronunciation. International Journal of Research in English Education (IJREE), 2(3).

Rodinadze, S., \& Zarbazoia, K. (2012). The advantages of information technology in teaching English language. Frontiers of Language and Teaching, 3(5), 271-275.

Schwartz, S., \& Pollishuke, M. (2013). Creating the dynamic classroom: A handbook for teachers (2nd ed.), Toronto, ON: Pearson.

Shyamlee, S.D., \& Phil, M. (2012). Use of technology in English language teaching and learning: An analysis. Proceedings of the International Conference on Language, Medias and Culture, Singapore, 150-156.

Solanki, D., \& Shyamlee1, M. P. (2012). Use of technology in English language teaching and learning: An analysis. International Conference on Language, Medias and Culture IPEDR vol. 33. IACSIT Press, Singapore. 150-156.

Tomlinson, B. (2009). Materials development in language teaching. Cambridge: Cambridge University Press.

Warschauer, M. \& Meskill, C. (2000). Technology and second language learning. In J. Rosenthal (Ed.), Handbook of undergraduate second language education (pp. 303-318). Mahwah, New Jersey: Lawrence Erlbaum.

Zhao, Y. (2013). Recent developments in technology and language learning: Literature review and metaanalysis. CALICO Journal, 21(1), 7-27. 